ISLLAC : Journal of Intensive Studies on Language, Literature, Art, and Culture

Journal homepage : $\underline{\text { http://journal2.um.ac.id/index.php/jisllac }}$

\title{
Serat Babad Kediri, Chronicle Of Figuration, Meaning, and Perspective: Among the Mythology, History, and Fiction
}

\author{
Sunoto* \\ Faculty of Letter, State University of Malang, Indonesia
}

\section{A R T I C LE INFO}

\section{Keyword:}

Figuration

Babad

Chronicle

Mythology

Fiction

History

\begin{abstract}
A B S T R A C T
Indonesia has a wide range of the literature types. This archipelago is enriched by ancient literature that becomes the works of man in the history. Inside the Javanese literature, there is manuscript which also called as "BABAD", this chronicle is separated depending on where each comes from, such as Babad Tanah Jawi, Serat Babad Kediri, Babad Ayat, Babad Ronggolawe, Babad Sumenep, and others. Each of that ancient manuscript, are inside the figuration, it because, those are present the three characteristics, that wraps by myth or legend, but at the same time, it was trying to represent the history of the land, and as well as enrich the Indonesian fiction literature. From a mythological perspective, figures in chronicles are beliefs or masks that are deliberately guarded and maintained by their owners. Therefore, the focus of the assessment is not to find the speaker's experience but to reveal the mask that is deliberately worn on the character. From a historical perspective, the figures in the chronicle are known to correspond to the life of the person concerned while in the primary time, or real facts. Therefore, the focus of the assessment lies in the attempt to find a correspondence between the facts mentioned therein with the fact that there is present in real life, as well as to observe from the primary interactions. Here's a fictional perspective, a chronicle is a world of fictitious life that is deliberately embodied in meaningful language. Therefore the focus of this assessment is trying to reveal the imaginative or symbolic worlds. On each of the Babad manuscript, it's associated with the message that brings out by the messenger which embed inside the context of value and meaning. This paper focused on the Babad Kediri manuscript that written out by Mas Ngabehi Purbawijaya and published by "Boekhandel TAN KHOEN SWIE", at the city of Kediri around 1932. It was a focus on the characterizing for the figuration inside the chronicle, from the view of myth, history, and fiction point of view.
\end{abstract}

(C) 2017 ISLLAC Journal. All rights reserved

\section{INTRODUCTION}

The focus of the discussion of this article based on Serat Babat Kediri (SBK) by Mas Ngabehi Purbawijaya (MNgP), published and circulated by a publisher named "Boekhandel TAN KHOEN SWIE", on the city of Kediri around 1932. This story was originally written in Javanese and writes using the Javanese letters. The results of

\footnotetext{
* Corresponding author.

E-mail addresses: sunoto.fs@um.ac.id (Sunoto)
}

2597-7385/ C 2017 ISLLAC Journal. All rights reserved. This is an open access article under the CC BY license (http://creativecommons.org/licenses/BY/4.0/).

6 | ISLLAC : Journal of Intensive Studies on Language, Literature, Art, and Culture 
tracking for the document of research, both on the virtual library and universities in Indonesia, this text has not been studied from the perspective of myth, fiction, and history. In 1936 in Batavia, in the publication of Balai Pustaka (Series 846), it is known there is a writing with the title Panji Gandrung Anggreni. The publication, after searching, illustrates only the tragedy of Panji's love with a woman called Dewi Anggreni. Then in 1940 known R.M.Ng Dr. Poerbatjaraka writes in Dutch verse with the title, Panji-Verhalen Onderling Vergeleken, published by A.C Nix \& Co-Bandung. The book does not review the lives of its characters from the myth, fiction and history also, but it still becomes a tradition and legend which live inside the Javanese peoples till this day, where it represents on the arts, dance and other intellectual property. Around 2003, Ms. Siti Halimah Soeparno known handed out the manuscripts to Imam Mubarok- RADAR Surabaya journalist -in the form of translation of "Serat Babat Kadhiri. The text after being examined is also not in the form of research, but only the translations. In 2004 Yeni Pratiwi, a student of Department of Indonesian Literature FS UM examine SBK text (Tesis) with title "Value Analysis inside the Babat Kediri Story", those theses are focusing on finding the values in the text. A common study also did not mention the characters in it from the perspectives of myth, fiction, and history, but only to reveal the inscribed value in the story, from the perspective of understanding and meaning of the researcher.

Due to the facts, this article intends to contribute positively (i) to the formation of the literary appreciation of the Nusantara literature, that the study of the life of the characters in the chronicle in general, especially the Babad Kediri (SBK) will be great benefits to find out the "red threads" on the long journey of cultural history, especially in the field of literature, and moreover when considered from the standpoint of characteristics, (ii) for the preparation of the historiography, for the world-life of the characters in the perspective of Indonesian Literature, (iii) for the development of awareness of many parties to conduct follow-up assessments, especially to texts or text of other old stories, which until now still like the dense forest has not much touched.

Start with that purpose, this article will specifically answer the question, "what was embodied, and figuration by each of the character inside the SBK wrote out by the MnGP?" The answer to that question is presented in the form of a character review found in the SBK text when considered from the perspective of mythology, history, and fiction.

\section{METHOD}

The question of the problem is answered using a qualitative approach (Sulistyorini et all, 2017: 29; Creswell and Poth, 2018: 65), combined with a historical, phenomenological approach. The preference option is based on the consideration of data raised in this article rather than statistical data in the form of numbers, but qualitative data in the form of verbal quotes (words, sentences, fragments) of the SBK text. The data is obtained through the act of repeated reading in depth. The following considerations of the three approaches used, namely historical, and phenomenology. The historical approach is chosen and used to know the characteristic of the characters mentioned in SBK if it is related to the facts found in the history of Javanese society. The restriction on the locus of Javanese society according to the setting and atmosphere of the story found in the text of SBK, i.e the society on the span of time and time before the Hindu royal government stood in Java until the collapse, spliced by the government of the Islamic empire until its low tide, spliced by the Dutch colonial government until leaving in the year 1942, spliced with the NKRI government of 1945 until now in 2017, and will be maintained until infinite time. The phenomenological approach is used to understand and interpret facts and data SBK figures by basing the concept of mythology and literature as the knowledge and experience of the storyteller, namely $M N g P$ in understanding the primary life of Javanese society in a certain time and space continuum.

The approach method is based on the following considerations. SBK is not because of his own will, but as a manifestation of $M N g P$ action in interpreting his expectations about the life of Javanese society. The action of MNGP in realizing SBK is inextricably tied to the experience and knowledge of Javanese life in the continuum of space and primary time. In such understanding, SBK means it can seat as the embodiment of the MNgP phenomenon of thought to what is known, experienced, though, expected to the Javanese society.

When considered from the phenomenon of fiction, the SBK is understood and interpreted closely with MNGP subjectivity. When considered from the historical phenomenon, the SBK closely with the objectivity of the facts of life of primary Java community that is known MNgP in certain periods of space and time. When considered from the phenomenon of myth, the SBK closely with the trust MNgP or Java community in a period of time and space.

Such understanding can be given an explanation as follows. The figure is found in autonomous fictional phenomena because the ability of narrators to create world-life figures is a necessary requirement. The obligation is different for historians. For historical historians, the creation of a life-changing world is a condition that must be avoided, as historical historians are bound by the principle of coherence in order to unite their subjective knowledge and subjective experience coherently and correspond with their sources. In contrast to history, fiction 
practitioners are just a must-walk way to freely greet their readers through the world-modeling of their storystory characters, which are imaginative symbolic worlds. Because of that, literary literature can open the opportunity to enrich the reader's experience, understanding, and understanding through the world of life, will, and acts of fictitious creation or fiction that will be held in order to embrace the imaginative symbolic world of life. Opportunities in the form of experience and understanding of the inner world will not be obtained readers when dealing with names of historical story figures and also include mythological figures.

The explanation suggests different historical and fictional characters because of the limitations the narrator must fulfill. For literary narrators, it is necessary to develop a world-class model of the character, while historical historians are obliged to avoid the creation of the world of character life to maintain the correspondence of characters with world-life facts in primary and primary time.

So, what is different subjective narrator fiction and myth? In this case, Kuntowijoyo (2002: 39) explains the difference as follows. The mythical story can' $t$ inherit as the narrator's experience through the creation of the world of character life since myths are not the reenactment of the narrator's experience. The subjectivity of a mythical narrator is not to pass on the experience but to the key to seeing or describing the work of his mind for what is being postulated. For the sake of maintaining that key, the story narrated in myth focuses on what matters most to the character and not the storytelling style. As a result, for anyone who intends to know and understand the mythical figure must be able to find and mark the form of relationships are arranged among the characters of the characters as the key to understanding, not to find a way of telling the story of the character of the life of a character. This limitation leads to the understanding that messages encoded in mythical stories, from cultural to individual levels, are maintained because the loyalty of the speaker maintains the key of relationships arranged between the characters of his characters. Therefore, for anyone who explores the mythical story is indirectly claimed to be able to understand and solve the hidden message behind, the mask or codes of relationships between characters instead of trying to find the way the speaker embodies the life of a person who is descended

From the above explanation, it can be emphasized the difference in the subjectivity activity of historians, fictions, and myths as follows. (1) The subjectivity of historical narrators is bound by the principle of coherence and correspondence. Coherence to produce factual claims of chaos, while correspondence to keep the historical life conformity with the author's primary source of subjective experience. (2) The subjectivity of fictional narrators is not bound by the correspondence limitations, as historical narrators, but instead focuses on the creation of a world-life model as "conditio sine qua non", the conditions that must exist, so that freelance writers create space and time, the imaginative world of imaginative life to realize the will and actions of his creative character as the message encrypted to be submitted to his receptor. Without the creation of a world the imaginative symbolic life, the fictional narrator would never produce his own experience, though, and subjective will in the form of the will and actions of his creative and creative creations. Here is, (3) the subjectivity of the mythical narrator. It turns out the subjectivity of the myths does not need to pass through the experience, but rather focuses on maintaining the top-down or the relations code of the character, which is being told.

The limits of historical conception, fiction, and myth as described above in this article are used as norms in finding characteristic figures present in SBK. With the use of these norms, it is expected to obtain a general description of characteristic characteristics in the story of a chronicle that became one of the wealth of literature of the archipelago.

\section{DISCUSSION}

To find out the characteristics of the embodiment of SBK figures with three approaches or point of view are used data in the form of quotations deliberately picked from locus and SBK text source. The quotation is shown as the original, Javanese and Javanese script (letter). Displayed thus to preserve the authenticity of the text, so for readers who intend to trace the truth, the data can be traced back to the original text. Then followed by the transfer of letters or the alphabet, from the letter or script of Java to Latin. This action is intended for readers who are not familiar with Javanese characters or letters but still can recognize and understand Java language get the ease, and the opportunity to sharpen back his understanding of the Java language that has begun to be pressed from his living memory. After that also followed by the translation into Indonesian and with Latin letters. This action is done so that readers who do not know Java language also get the ease, which can understand the understanding of quotations in Indonesian text.

By presenting such data, the discussion of characteristic characteristics by utilizing the three approaches or points of view is as follows.

\section{SBK Figure from Mythological Approach}

To find a character SBK characteristic of mythology used data as below. The figures encountered in the following quotations prior to being categorized as mythological figures in advance to find common characteristics

\section{8 | ISLLAC : Journal of Intensive Studies on Language, Literature, Art, and Culture}


possessed by each character found. Characteristics of the general character are directed to the classification of invisible bearing bodies and bodied incisors are often called spirits. After knowing the limits are then forwarded by tracking the existing figures or called on the following quotation.

\section{$1^{\text {st }}$ Quotations}

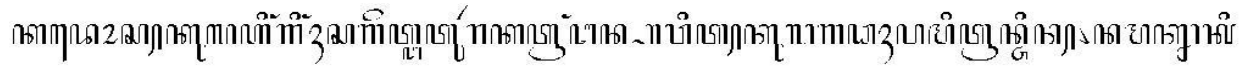

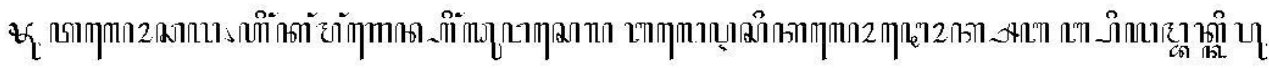

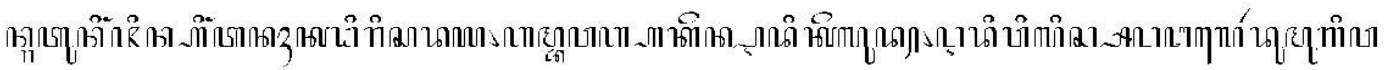

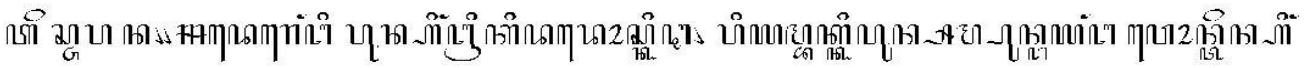

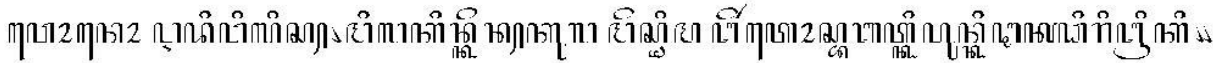

kados kula inggih saged ngaturri katrangngan awit kula gadhah pamitran Jin, namaknya Ki Butalocaya, ingkang manggen wonten ing Guwa Selabale Redi Kalothok, sabab piyambakkipun ratunning Jin ing tanah Kadhiri sadaya, ambawahhaken redi Kelud, redi Wilis sapangaler dumugi Wates Japan. Saderengngipun ing ngriki dados kitha, piyambakkipun sampun ngayang ngawonten ing wana redi Wilis, mila kinten kula mesthi mangertos babattipun Kitha Kadhiri ngriki.

I seem to be able to tell you because I have spiritual friends, Jin, Named as Ki Butalocaya, he lives at Guwa Selabale, Klatok mountain. Ki Butalocaya is the king of Jin in the Kediri region, including Mount Kelud, Wilis up to Wates Japan. Before the area became the town, Ki Butalocaya already located and wandering in the forests of Wilis Mountain, therefore I sure understand about tripe his city Kediri

\section{$2^{\text {nd }}$ Quotations}

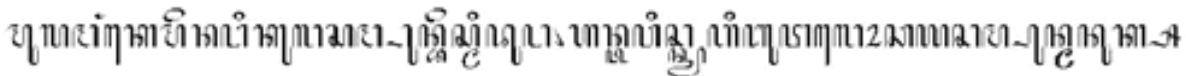

ขางภริเหกำ 2า2

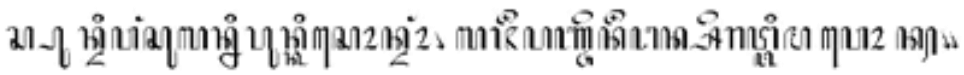

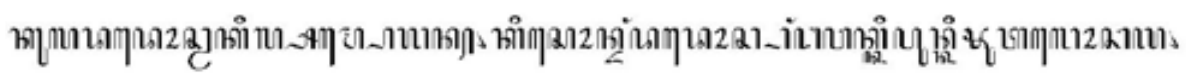

.kula dados wakil sampeyan, Ki Sondong dados pangawakkipun Ki Buta locaya, mila mangke menawi kula sampun besmi dupa, antawis Kyai Buta locaya sampun manuksa madhateng ki Sondong, kula wakil Sampeyan ajeng pitaken dhateng Ki Sondong, kados pundi wangsulannipun Ki Sondong, lajeng panjenengan seratti kemawon.

Free translations, such as the following.

I became the representative of Mr. Ki Sondong so the manifestation of Ki Butalocaya, therefore if I have burned incense, and Ki Butalocaya has come to come together Ki Wondak Sondong body, I will ask the representative of Ki Sondong, what kind of answer Ki Sondong, then you just write it.

In the 1st and 2nd quotations above are found the following figures: Jin, Bapak ( the name for the figure Mas Ngabehi Purbawijaya - MNgP - narrator), Ki Sondong, Ki Butalocaya. Of the four names of characters found in excerpts 1 and 2 above the Jin figures, ratuning Jin, Ki Butalocaya can be categorized as mythological figures. The other two figures, Bapak and Ki Sondong, can be thought of as names of characters with historical and/or fictional characteristics. 
The Jin figure, or returning Jin, Ki Butalocaya is categorized as a figure with mythological characteristics which can be explained as follows. The three figures are classified as mythological figures identified from the following statement-kula gadhah pamitran Jin, namaknya Ki Butalocaya, ingkang manggen wonten ing Guwa Selabale Redi Kalothok". This sentences-kula gadhah pamitran- means he has friends in the daily speech practice, not mythical activities. It will shift to myth if that pamitran word, meaning that friend is Jin, the class of spirits. It is interpreted that, the character with the title of Jin is not found in the primary fact, but on the space of idealism. The understanding is also supported by the following statement, Ki Sondong dados pangawakkipun Ki Butalocaya, mila mangke menawi kula sampun besmi dupa, antawis Kyai Buta locaya sampun manuksa madhateng ki Sondong, kula wakil Sampeyan ajeng pitaken dhateng Ki Sondong." On the statement Ki Sondong dados pangawikkipun Ki Butalocaya means that Ki Sondong getting trance and became Ki Butalocaya. In the event of the primary speech into Ki Butalocaya - spirits - means to be in a state of possessed soul of the astral. In such conditions, the physical sign (fisionomo) which includes the gestural and verbal of a possessed man is no longer his, but the possession of the infecting soul. If this practice is used as data, then the data obtained is not valid, because the information submitted smooth through the media spoken Ki Ki Sondong can't be verified. With another insight, a deliberate creature invited by burning the singing and then penetrating the rough body of Ki Sondong is a mythic act, meaning unmeasurable because the behavioral marks found do not illustrate the fact that something is being traced with sensory devices. As a result, the speech event is not in natural or natural practice but is in mystical speech. Therefore, the information or instructions given by a person who is being possessed by a spirit is rejected by the principle of obtaining facts and data in scientific work. Consequently, such information or guidance is only up to the limit believed by those who practice such speech and can't be verified according to the scientific work principle, induction - deduction - verification.

With so can be emphasized, in practice said that the character mentioned is a characteristic character of the myth, because the existence of Jin, ratuning Jin, Ki Butalocaya can' $t$ be traced to the fact of place or primary reality at the locus Guwa Selabale redi Kalathok, namely Selwa guwa on Klatok mountain. Indeed a place called Guwa Selabale redi Kalathok is a fact, characteristic of history, but the existence and actuality of Jin, ratuning Jin, Ki Butalocaya cannot be verified, as it is in the mythical area. That way, about the action of a creature named Jin, ratuning Jin, Ki Butalocaya is also not the re-embodiment of the MNgP experience of the primary actuality, but the embodiment of MNgP trust or community in Kediri in the royal period Kediri, around the 12th century on what they perceive or perception to exist (Kuntowijoyo 2002: 39).

\section{SBK Character from Historical Approach}

The existence of characters characterized by history in SBK can be explained by using the quotation below. The characters found in the quotation before being concluded as historical figures are first traced by corresponding to the facts found in the natural locus or the primary locus in the field. Tracking must be done to meet the principle of correspondence that became typical of history. With these considerations, the quotation below can be referred to support the discovery of characters characterized by SBK history.

\section{$3^{\text {rd }}$ Quotations}

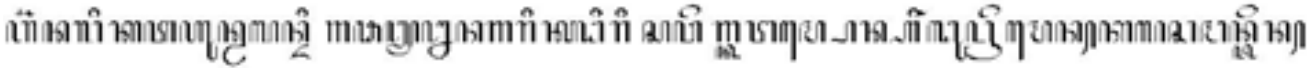

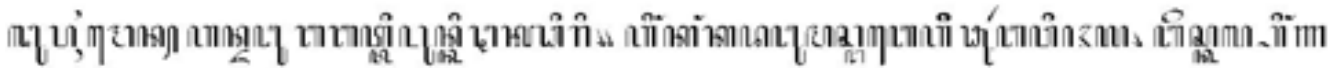

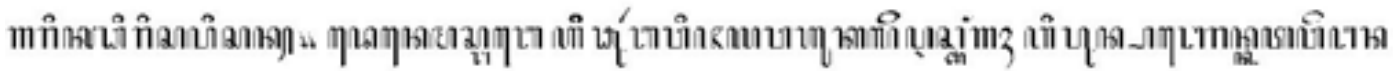

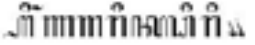

.........Ing nalika Tahun Walandi 1832, Nagari Kadhiri saweg mentas katampen ing Gupremen. Kala samanten Gupremen andangu babattipun Kitha Kadhiri. Ingkang kadangu Mas Ngabehi Purbawijaya, beskal ing Nagari Kadhiri sapisan. Dene Mas Ngabehi Purbawijaya wau kaleres canggahhipun Pangeran Katawengan ing Nagari Kadhiri.

Coinciding in the year $1832 A D$, Nagari Kediri recently received the arrival of Gupremen who intend to seek information Kedat Kediri. The asked is Mas Ngabehi Purbawijaya, first beskal in Nagari Kediri, still a vocal Pangeran Katawengan in Nagari Kediri. 


\section{$4^{\text {th }}$ Quotations}

Raden Lembu Amerdadu, kadadossaken ratu wonten ing Daha, ajujuluk Prabu Pujanningngrat. Raden Lembu Pangarang kadadossaken ratu wonten ing Ngurawan, ajujuluk Prabu Pujadewa. Raden Lembu Amerjaya kadadossaken ratu wonten ing Panaraga, ajujuluk Prabu Pujakusuma. Raden Lembu Amerdadu was appointed king in Daha, named Prabu Pujaningrat. Raden Lembu Pangarang was appointed king in Ngurawan, named Prabu Pujadewa. Raden Lembu Amerjaya was appointed king in Panaraga, named Prabu Pujakusuma.

The historical markers on quotes 3 and 4 above are known from the title Gupremen, Mas Ngabehi Purbawijaya, Prince Katawengan. The title of the historical Gupremen of historical figures can be traced back to primary facts and data, ie on the span of Dutch colonization space and time in Java. It can be traced to history textbooks in elementary and secondary schools, that the title of Gupremen refers to the name of the Dutch who served colonial rule in Batavia. The colonial government was known as a continuation of VOC dominance in trade activities in the archipelago since coming to Ternate in $1615 \mathrm{AD}$ and then shifted into Java, namely in Batavia or Sunda Kelapa in 1619 AD

Next, mention Mas Ngabehi Purbawija after traced to the primary facts in Kediri known to refer to the first prosecutor appointed by the Dutch colonial government for the Kediri region. Then, if traced to the lineage of his descendants, Mas Ngabehi Purbawija is the son of Prince Katawengan, the level officer of the subdistrict head who ruled during the period of the royal government of Yogyakarta Sultanate. Means after the kingdom of Mataram broke into two, namely Kasunanan Surakarta and Kasultanan Yogyakarta through the agreement Giangti Salatiga to date. 13 February 1755 AD by the Dutch colonial government with the Sultanate of Mataram. The agreement is a sign or the demarcation of the fully independent independence of the Mataram Sultanate. After that, the government in Java is run by two Islamic kingdoms, namely Kasunanan in Surakarta and Kasultanan in Yogyakarta under the shadow of Dutch colonial control in each region that has been fixed on the agreement Gianti.

Characteristics of historical figures on SBK as described above are also supported by the statement of Walandi 1832 and Nagari Kadhiri. Both titles are interpreted as loci or historical markers because they correspond to facts and data that can be traced to the reality of primary reality (Pranoto 2006: 4). Walandi's declaration of the year, that is, the year of the Netherlands is the year of Christ, as the calculated calendar refers to the rotation of the sun. Therefore, if based on the number $1832 \mathrm{AD}$ and then withdrawn to the number $1619 \mathrm{AD}$, the early entry of the VOC in Batavia, it can be seen that the Dutch colonialization in Java has lasted for 213 years. Then if the $1832 \mathrm{M}$ number is drawn forward to 1922 as the SBK issue number, it can be calculated the estimated SBK write down about 303 after the Dutch colonialization in Java. The 303 years number is calculated from the reduction $(1832-1619)+(1922-1832) \rightarrow 213+90=303$

Furthermore, if the number of years used as a benchmark to track the existence of SBK figures from the historical approach, then still need to be supported or verified with facts and historical data outside SBK. Such facts and data include facts and data of artifacts and manuscripts which prior to use as historical sources of support also need to be verified from the point of view of primary natural reality.

Beyond the time marker as explained above the name of Kediri is a landmark. In the map of the legend of East Java, Kediri is the name of the capital of Kediri district with a predetermined region boundary. His government called the district government headed by a Bupati. In the map of East Java Province, the regent of Kediri together with other regents in the territory of East Java province under the government of a Governor.

The residual question that needs to be answered after referring to the facts is as follows. Is the title of governor for the territory of the territory of the Republic of Indonesia is a transformation of the title of gupremen in the Dutch colonial government in Batavia? Please find and find the answer yourself!

\section{SBK Figures from the Fictional Approach}

If the SBK character is highlighted from a fictional approach, especially fictional prose, it will refer to the existence of a symbolic (lebenswelt) world of life deliberately engineered by the storyteller, MNgP. The symbolic world of life is deliberately engineered so that individual and social acts of individuality in the unity of the story become manifest as if there is something to be found in everyday life. As a result, the names, thoughts, characters, and actions of the characters, as well as the settings and atmosphere encountered in individual and social acts of symbolic life are also understood as characters' names, thoughts, characters, and actions, and symbolic-fiction setting and atmosphere.

To legitimize this understanding the following quotation is used. 


\section{$5^{\text {th }}$ Quotations}

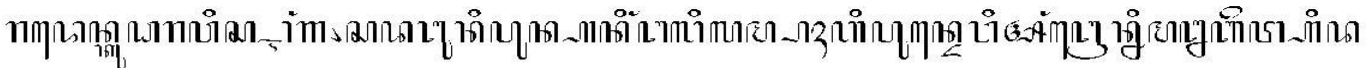

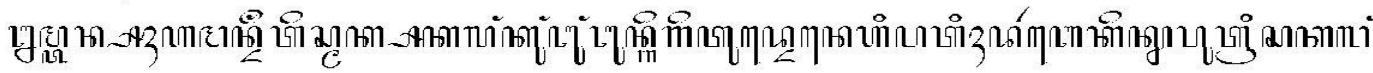

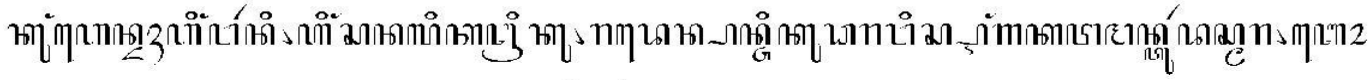

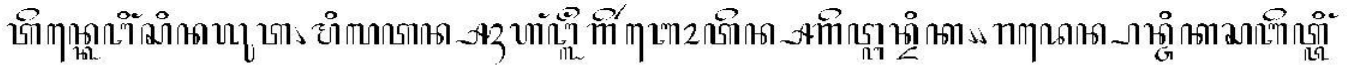

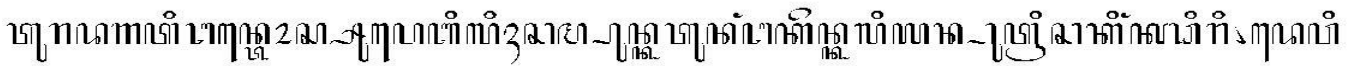

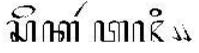

.......Raden Kudarawisrengga, sadangunipun aningali lampahipun Dewi Angreni malebet ing dalem tansah amandeng kedhep tesmak, sakalangkung ngungun gegetun dene ipatih darbe kenya putri sakalangkung endahing warni. Ing sanalika ngriku, Raden Panji Kudarawisrengga kamanturda smara, boten kenging sinayuta, mila tansah anglengger boten saget ngandika. Raden Panji kasabeting turidagati ngantos supe bilih sampun katunangaken kaliyan putri saking Kediri, Dewi Sekartaji.

Free translations, such as the following.

As if hit by an anesthetic, Raden Kudarawisrengga without winking eyes watching Retna Angreni where to go. There was a sense of waves in his soul, every pounding of Retna Angreni's steps became more real, though the figure of Retna Angreni vanished to slip behind the door of the train house. Feelings Panji masgul, not satisfied looking at the beauty of retna Angreni paras, but long-awaited no longer dare to appear. Nevertheless, there was no angry strokes on Panji's face, only a streak of wonder and wonder. Apparently in Jenggala practice grow a beautiful flower, beautiful. Since the encounter, the heart of Panji liver broken penetrated by the elegance of Retna Angreni. No more considerations that can overcome his will, Panji's body and soul moored in the elegance of Retna Angreni, to forget that has been mated with Dewi Sekartaji, Princess of Kediri.

\section{$6^{\text {th }}$ Quotations}

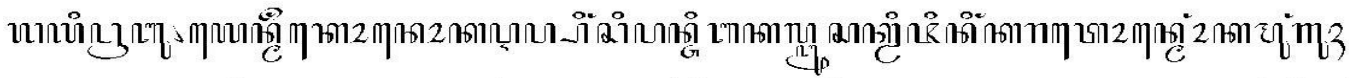

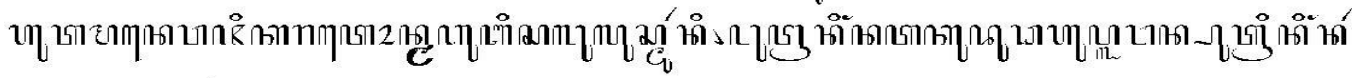

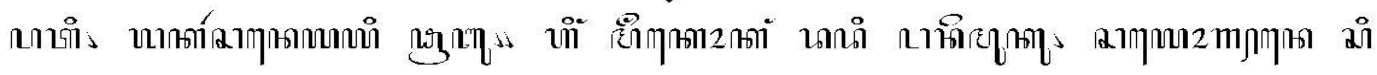

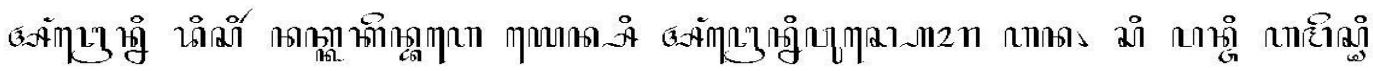

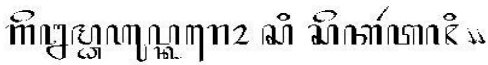

Yayi prabu, yen mengkono kareping si Panji bakal ngrusak wijining karaton, mongka mungguh utamane, wiji karaton mau bisa lulus murni, putraning nata kudu daup lawan putrining Narpati, kaya karsane yayi Prabu. Ing mengko kang dadi panemuku, sayogyane si Ngreni disirnakaken bae, yen si Ngreni wus ora ana, si Panji amesthi gelem daup karo si Sekartaji.

Free translations, such as the following.

Prabu's brother, then the wish of the Panji married the Angreni means will damage the palace seed. Prabu's sister must realize that the palace seed will be able to pass purely if the prince marries the daughter of the queen, like the will of Prabu's younger brother. To resolve the confusion in my opinion there is no other way unless Angreni is annihilated. If the Ngreni is gone, the Panji will want to marry the Sekartaji. 
The names found in $5^{\text {th }}$ and $6^{\text {th }}$ quotes above, namely Raden Kudarawisrengga, Retna Angreni, Dewi Sekartaji, Yayi prabu (citation given by Resi Kilisuci to King Jenggala) are categorized as fictional characters, or symbolic figures because of thoughts, attitudes, characters, and the individual and social acts of individual characters can't correspond to primary facts and data.

That understanding is supported by statements, Raden Kudarawisrengga, sadangunipun aningali lampahipun Dewi Angreni malebet ing dalem tansah amandeng kedhep tesmak. This statement, aningali lampahipun Dewi Angreni, meaning when seeing the goddess Angreni walking, the eyes of Raden Panji Kudarawisrengga not blinking like glasses that never blink. Such a statement is not an actuality that can be photographed in primary facts or natural facts when the raden Panji Kudarawisrengga meets the Goddess Angreni at certain primary times and places. Because the behavior and settings encountered in the fragment are symbolic. With such a description then the act, place, and atmosphere or social event become manifest. The depiction is a story style deliberately created by $\mathrm{MNgP}$ in communicating a message that intentionally encryption on SBK can arrive at the map of its receptor meaning. It is not a fact and historical data nor is it a myth, but a symbolic world of life that is intentionally created or fancied by $\mathrm{MNgP}$ so that what is embodied in the symbolic world of life seems as real as the actuality of primary life, just like the past tense act.

From the above discussion can be found additional variables to be used as a consideration in classifying characteristics of characters in the chronicle if used mythological, historical, and fiction approaches. The additional variables in question are beyond the main variables, namely the mythological, historical, and fictional conceptions of the nature and nature of different substances. Additional variables in question are as follows. (1) The general classification of creatures that have become common knowledge, including profane and mortal. Called a profane being, because, it is frail, measurable, can be broken down, and can be damaged. Also called the rough-bodied, "wadag" (Javanese). Then it is called mortal, because it is not sensed, does not sound, is immeasurable, can't be decomposed, and can't be damaged. Profane beings are also understood to live in primary space and time, but with the name of subtle and immaterial beings. If the supernatural being is located in space and in the primary time, the fact can't be verified, but only in the realm of belief or belief, or the domain of myth. Because it is called mythological creatures. That way, the group of profane beings and historic nature, while the mortal is not nature and historic nature. (2) The profane can be in mythical condition, if the predicate attached to the profane subject is on immeasurable actions or mythic actions, as they can't be verified. For example, my teacher yesterday told me his grandfather who had died two years ago. In the example of the sentence, the teacher is a profane figure, but his actions enter the mortal space because it can't be measured or verified. The predicate marker, indicating that the subject or teacher in the sentence is mythical. Or with another statement, the teacher believes in a mythical creature or a mortal, mythological creature.

\section{CONCLUSION}

From the description above, can be concluded, that the text of the chronicle is a work of fiction or custom work. If it found a myth or historical figures does not mean a chronicle is a myth or history. The mythical or historical figures encountered in the text of the Chronicle should be addressed as a tool deliberately presented by the chronicle narrator so that the characters become manifest or manifest as found in the primary or real life. That's why the reader of the text of the chronicle becomes likely to be able to dialogue with historical figures, myths, and/or fictional characters deliberately presented by the storyteller in imaginative symbolic life. With another insight, the text of the chronicle is a fictional text that can be positioned and functioned as a subjective dialogical field to reach the realm of history and myths that once existed, and existed within the continuum of primary space and time past.

That is the richness and uniqueness of the chronicle text. If the reader intends to know more deeply about the life of the historical figure found in the chronicle text it can be compared with artifacts or archeology data pertaining to the characters. If the reader intends to know or uncover a mask deliberately imposed on a mythological figure may trace the character from the point of view of ceriteme, miteme, and his period as suggested by Claude Levi 'Strauss in the study of mythical structuralism.

\section{REFERENCES}

Atmadja, N.B. (2010). Genealogi Keruntuhan Majapahit. Yogyakarta: Pustaka Pelajar Azzam, A.R. (2007). The Kingdom of Joy "Untaian Kisah Menawan dari Matsnawa Rumi (terjemahan). Bandung: Hikmah Burke, P. (2001). Sejarah dan Teori Sosial. Jakarta: Yayasan Pustaka Obor Indonesia. Danesi, M. (2012). Pesan, Tanda, dan Makna. Yogyakarta: Jalasutra. Decartes, R. (2012). Diskursus dan Metode (terjemahan). Yogyakarta: IRCiSoD Ewing, A.C. (2003). Persoalan Mendasar Filsafat. Yogyakarta: Pustaka Pelajar Fay, B. (2002). Filsafat Ilmu Sosial Kontemporer(terjemahan). Yogyakarta: Jendela 
Frondizi, R. (2001). Pengantar Filsafat Nilai (Terjemahan).Yogyakarta: Pustaka Pelajar Purbawidjaya, M.N. (1932). Serab Babad Kediri. Kadiri: Boekhandel TAN KHOEN SWIE

Rahardja, S. (2011). Peradaban Jawa. Jakarta: Yayasan Kertagama

Sulistyorini, D. et all . (2017). Cultural Commodification: Representation Of Pesarean Of Mount Kawi As Cultural Tourism In Indonesian Mass Media. ISLLAC Journal of Intensive Studies on Language, Literature, Art, and Culture Vol. 1 No. 1 September 2017

Thorpe, S. (2005). Berfikir Cara Einstein (terjemahan). Batam: Interaksa

Vlekke, S.H.M. (2008). Nusantara Sejarah Indonesia (terjemahan). Jakarta: KPG

Creswell, J.W. and Poth, C.N. (2018). Qualitative Inquiry and Research Desain: Choosing Among Five Approaches. United State America: Sage Publications, Inc. 